\title{
Heterosexual Response to Playback Calls of the Leach's Storm-Petrel Oceanodroma leucorhoa
}

\author{
Miki Taoka*, Tetsu Sato*1, Tsutomu Kamada*2 and Hiroshi Okumura*3
}

\begin{abstract}
Four calls of the Leach's Storm-Petrel (Oceanodroma leucorhoa), the Chatter-calls and Purr-calls of both sexes, were played back from a loudspeaker on the ground near the colony in Daikoku Island. All the playback calls attracted birds in flight and elicited Chatter-calls from them. The sex of the attracted birds were judged by analyzing the Chatter-calls. Significantly more birds responded to the playback call of the opposite sex than that of the same sex. It has already been revealed that birds inside burrows respond only to the playback calls of the same sex. Therefore, in this study it was found that the same call can elicit responses from different sexes in different circumstances. Thus, the same call can have different meanings in different contexts.
\end{abstract}

In animal communication, it is said that the same signal can elicit different responses under different contexts and this enables a small repertoire size of certain species to have more functions in communication (Smith 1977, Catchpole 1982, Slater 1983). The Leach's Storm-Petrel (Oceanodroma leucorhoa), a nocturnal seabird, has only a few call types such as the Chatter-call, Purr-call and Screech-call (Cramp \& Simmons 1977, Taoka et al. 1988). Since birds are active only at night in the breeding colony, these vocalizations may play an important role for communication (Grubb 1973, Taoka et al. 1988). The study on the vocalization of this species may contribute to understand how the small repertoire size achieve the needs of communication. In the present study, the response of birds to the same calls was investigated in different contexts.

The Chatter-call shows the sexual dimorphism and functions as sex recognition; birds can discriminate the calls of both sexes and respond only to the playback calls of the same sex when it is played back to birds inside their nesting burrows (Taoka et al. in prep.). Chatter-call is given in various situations; birds give it in flight, on the ground and inside the burrows (Taoka et al. 1988). Birds on the ground or inside burrows often give Chatter-calls with other call types, Purr-calls and Screech calls. We divided Chatter-call vocalizations into four categories according to what call is accompanied with Chatter-call: Chatter-call alone; Chatter-call with Purr-call; Chatter-call with Screech-call; and Chatter-call with wheeze part of Purr-call. Each of them was found to be given in a specific situation, for example, Chatter-call alone was given between a male and a female inside a burrow. It seems that Chatter-calls have different meanings in different situations. Purr-call is mainly given in a specific situation; in the burrows where a male-female pair before egg-laying is present (Taoka et al. 1988). However, playback of Purr-calls to birds

Received 30 September 1988; accepted 25 November 1988

*, *3 Department of Biology, Japan Women's University, 2-8-1 Bunkyo-ku, Tokyo 112

*1 Department of Zoology, Faculty of Science, Kyoto University, Kyoto 606.

*2 Department of Oral Physiology, Hokkaido University, School of Dentist, Sapporo 060.

*3 To whom reprint should be requested. 


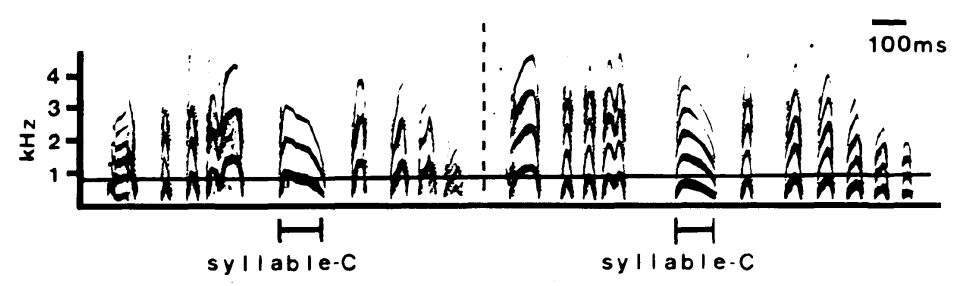

Fig. 1. Sexual dimorphism in Chatter-calls and sexing method by HFC analysis. These sonagrams are Chatter-calls of a male (left) and a female (right). HFC (the highest frequen- . cy within the fundamental frequency band of syllable-C) shows the sexual dimorphism, so the sex of bird can be judged by HFC analysis. The horizontal line indicates the boundary between the calls of both sexes.

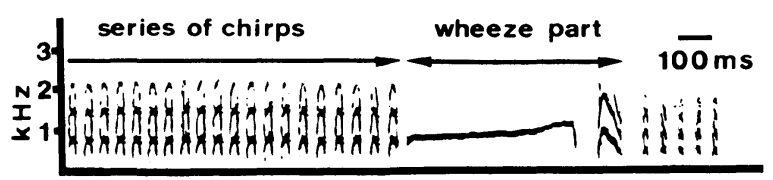

Fig. 2. Purr-call of a male. Purr-calls consist of a rapid series of chirps which is intercepted with a wheeze part.

inside burrows does not elicit significant responses from the opposite sex birds (Taoka et al. 1987). Grubb (1973) reported that playback of Purr-calls attracted birds in flight, when the calls were played back from the loudspeaker on the ground in their colony. Chatter-call also attracted birds in flight (Taoka, unpublished data). But the sex of the attracted birds has not been examined yet.

There are highly dense colonies of Leach's Storm-Petrels in Daikoku Island $\left(42^{\circ} 52^{\prime}\right.$ $\mathrm{N}, 144^{\circ} 52^{\prime} \mathrm{E}$ ), located off the coast of the easternmost part of Hokkaido, Japan. The breeding season is from May to September. Four test calls, the Chatter-calls and Purr-calls of both sexes, were played back at night from 2200 to midnight on July 19, 21 and 22,1986 . The loudspeaker $(8 \mathrm{~W})$ was placed on the ground where very few birds flew over, about $30 \mathrm{~m}$ from the nearest colony. The intensity of playback sound was adjusted to approximately $90 \mathrm{~dB}$ measured by a RION sound level meter NA-14, $1 \mathrm{~m}$ from the front of loudspeaker.

Test calls were recorded from the birds inside burrows in Daikoku Island, 1984. The Chatter-calls of both sexes (Fig. 1) were recorded from a pair, whose call durations were $1.1 \mathrm{sec}$ (the male call) and $1.3 \mathrm{sec}$ (the female call). Purr-calls consist of a rapid series of chirps which is regularly intercepted by a wheeze part (Fig. 2). For the experimental tape of the Purr-calls, a series of chirps followed by a wheeze part (about two second total duration)was taken from long recordings of each sex call. These test calls were recorded on cassette tape to be played back at the rate of once every five seconds. Each of them was played back for $10 \mathrm{~min}$ and was tested once in a day. These 10 minute periods were interposed with five to 20 minute periods of silence.

Chatter-calls given by attracted birds were recorded with a Sony cassette recorder TC-D5PRO and Victor shotgun microphone MZ-100. The microphone was set up to 


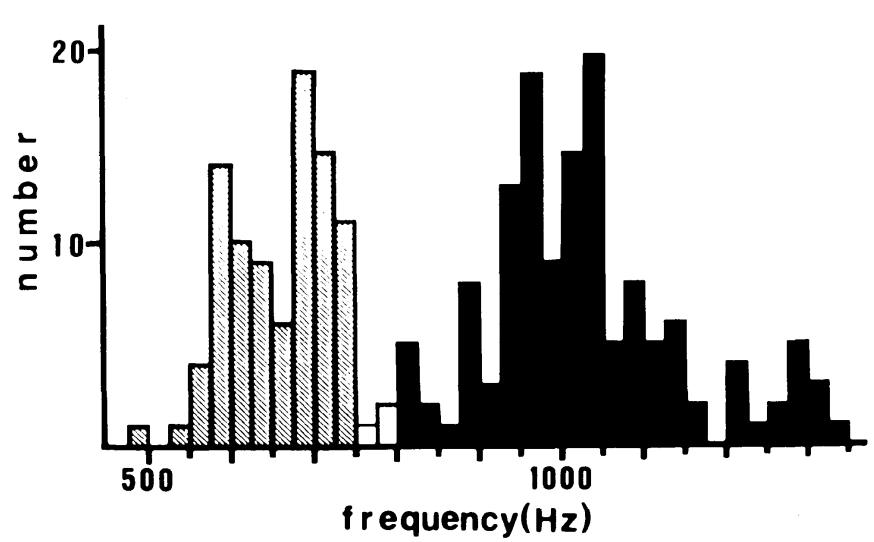

Fig. 3. HFC analysis of Chatter-calls given by attracted birds. The vertical axis indicates the number of calls and the horizontal axis indicates the frequency of HFC. There are apparently two separated groups. The calls of HFCs under $750 \mathrm{~Hz}$ (shaded bars, 90 calls) were judged to be those of females and calls of HFCs over $800 \mathrm{~Hz}$ (closed bars, 137 calls) were judged to be those of males. The remaining three calls of HFCs between 750 $\mathrm{Hz}$ and $800 \mathrm{~Hz}$ (open bars) were judged to be sex unknown birds.

direct upward at $1 \mathrm{~m}$ above the loudspeaker. The parabola was attached beneath the microphone for successful recording by diminishing the intensity of sounds of playback calls and the amount of background noise generated by seawaves or vocalizations from the nearest colony. The sex of caller can be judged by the analyses of the frequency components of recorded Chatter-calls (Taoka and Okumura 1988, Taoka et al. in prep.). In the previous study, we analysed Chatter-calls with sonagrams and found that the highest frequency within the fundamental frequency band of syllable-C (HFC) showed the sexual dimorphism; male HFCs were always over $800 \mathrm{~Hz}$ and female HFCs were always under $750 \mathrm{~Hz}$ (Taoka et al. in prep., Fig. 1). In the present study, HFCs were not measured with sonagrams but with power spectrograms obtained from the FFT spectrum analyzing system. This system was constructed of a 12 bit analog/digital converter board (20 kHz sampling, I/O Data Co.) and a NEC microcomputer PC-9801M. To ascertain whether these measurements differ from those of sonagrams or not, 32 Chatter-calls from 16 birds were analyzed by both this system and a Kay Sona-graph 7800 using $150 \mathrm{~Hz}$ filter. The differences between the two measurements of each call were usually very small, $13 \mathrm{~Hz}$ on average and $38 \mathrm{~Hz}$ maximum. Therefore, analysis of $\mathrm{HFC}$ with power spectrogram is also available for sexing with the same criterion as that with sonagram.

All test calls attracted birds and elicited Chatter-calls from them. However, they soon disappeared after playback periods. The sex of birds attracted was judged by HFC analysis (Fig. 3). Only 230 Chatter-calls were analyzed from 758 recorded calls owing to the relatively large amount of background noise generated by seawaves or wind. The Doppler effect may cause the frequency shift of calls of aerial birds. The mean $\pm \mathrm{SD}$ of HFCs of 137 male calls was $1030 \mathrm{~Hz} \pm 118$ and that of 90 female calls was $660 \mathrm{~Hz} \pm 58$. These values were very similar to those of birds inside burrows which were described in 
Table 1. Sex of birds responding to playback calls.

\begin{tabular}{cccccc}
\hline $\begin{array}{c}\text { Playback } \\
\text { calls }\end{array}$ & $\begin{array}{c}\text { Responses } \\
\text { of males }\end{array}$ & $\begin{array}{c}\text { Responses } \\
\text { of females }\end{array}$ & $\mathbf{P}^{* 1}$ & $\begin{array}{c}\text { Sex unknown } \\
\text { birds }\end{array}$ & $\begin{array}{c}\text { Total } \\
(n=230)\end{array}$ \\
\hline $\begin{array}{c}\text { Chatter-call } \\
\text { of a male } \\
\text { of a female*3 }\end{array}$ & 3 & 51 & $\ll .01$ & 2 & 56 \\
$\begin{array}{c}\text { Purr-call } \\
\text { of a male } \\
\text { of a female }\end{array}$ & 103 & 5 & $\ll .01$ & 0 & 108 \\
\hline
\end{tabular}

${ }^{* 1}$ : Significance levels of binominal test for the difference in the response between the sexes.

The differece between the responses of ${ }^{* 2}$ and ${ }^{* 3}$, and that of ${ }^{* 4}$ and ${ }^{* 5}$ were significant (chisquare test. $\mathbf{P}<0.01)$.

the previous study (Taoka et al. in prep.); that of males was $990 \mathrm{~Hz} \pm 95(n=33)$ and that of female was $650 \mathrm{~Hz} \pm 61(n=17)$. Therefore, the Doppler effect need not be considered.

The results of playback experiments are summarized in Table 1. Most of the attracted birds responded to playback calls of the opposite sex. The sex ratios of responding birds to playback Chatter-calls were significantly different between a male and a female playback calls. The same result was found in playback Purr-calls. So, the birds discriminated the calls of both sexes. The vocal sex recognition has already been demonstrated in Chatter-calls (Taoka et al. in prep.). As for Purr-calls, the sexual difference is present in frequency but only males discriminate the calls of both sexes when the calls are played back to the birds inside burrows (Taoka et al. 1987). Although the discrimination of Purr-calls of both sexes was demonstrated in the present study, there were relatively many responses of females to the playback of the female Purr-call (Table 1). These facts suggest the possibility that female birds descriminate the Purr-calls of both sexes only indistinctly. However, female can recognize the sex of the signaller of Purr-call because Purr-call vocalizations usually accompany Chatter-calls in the natural vocal behavior (Taoka et al. 1988).

In the playback experiments of Chatter-calls to the birds inside their nesting burrows, they respond with Chatter-calls only to the calls of the same sex (Taoka et al. in prep.). In case of Purr-calls, male birds inside burrows respond more frequently to male calls than to female calls (Taoka et al. 1987). The playback calls used in the present study were the same as those of previous studies (Taoka et al. 1987, Taoka and Okumura 1988); nevertheless, they attracted the heterosexual birds in flight when the calls were played back from a loudspeaker on the ground. These calls elicit sexually reversed responses in the different circumstances. Thus, the same signal more space has different meanings in different contexts. This may result from the different situations of signallers or the different motivations of recipients. In the other burrowing seabirds, it has been reported that birds inside burrows respond to the same sex call and was disccussed in relation to competition for mate or territorial deffense (Brooke 1978, 1986, Storey 1984, James 1985). Whereas, the heterosexual response in the present study is probably related to pair formation. Preliminary playback experiments were conducted in the earlier and later 
breeding season of 1985. In the beginning of June, more birds seemed to be attracted than in the present study and some of them landed near the loudspeaker. On the other hand, birds scarcely gathered above the speaker in late August, when most birds engaged in incubation or feeding. Post-egglaying birds doesn't seem to be attracted to the opposite sex call. Probably, attracted birds to the opposite sex are mostly premated birds. As for birds inside burrows, we observed that both the birds of pre- and post-egglaying responded to the same sex call. Although it is unknown that pre-egglaying birds are mated or premated, different meanings of the same call seem to depend on differences in motivations or states of recipients.

Leach's Storm-Petrels have only three call types in spite of importance of their vocalizations for communication. Yet, the multiple meanings of the same signal may enable the small repertoire to have more functions for their cmmunication.

We heartily thank Messrs. M. Nomura, T. Kasajima and Y. Miyakawa and also the Akkeshi Fishery Co-operative Association for their support of the field work on Daikoku Island. We also thank Miss T. Imanaga, an undergraduate student of the Biological Department of Japan Women's University for her hearty help in the field work. We are also indebted to the Board of Education of Akkeshi-cho for obtaining permission from the Agency for Cultural Affairs and the Environment Agency for the field work on Daikoku Island.

\section{References}

Brooke, M. de. L. 1978. Sexual differences in the voice and individual vocal recognition in the Manx shearwater (Puffinus puffinus). Anim. Behav. 26: 622-629.

Brooke, M. de. L. 1986. The vocal systems of two nocturnal burrowing petrels, the White-chinned Procellaria aequinoctialis and the Grey $P$. cinerea. Ibis 128: 502-512.

Catchpole, C. K. 1982. The evolution of bird sounds in relation to mating and spacing behavior. In: D. E. Kroodsma and E. H. Miller (eds.), Acoustic communication in birds, Vol. 1, pp. 297-319. Academic Press/ New York.

Cramp, S. \& Simmons, K. E. L. (eds.). 1977. Handbook of the birds of Europe, the Middle East and North Africa, Vol. 1. Oxford University Press/Oxford.

Grubb, T. C. JR. 1973. Colony location by Leach's Petrel. Auk 90: 78-82.

James, P. C. 1985. The vocal behaviour of the Manx shearwater Puffinus puffinus. Z. Tierpsychol. 67: $269-283$.

Slater, P. J. B. 1983. The study of communication. In: T. R. Halliday and P. J. B. Slater (eds.), Animal Behaviour, Vol. 2, Communication, pp. 9-42. Blackwell Scientific Publications/Oxford.

Smith, W. J. 1977. The behavior of communicating. Harvard University Press/Cambridge.

Storey, A. E. 1984. Function of Manx shearwater calls in mate attraction. Behaviour 89: 73-89.

Taoka, M. \& Okumura, H. 1988. Playback experiments of synthesized sounds in Leach's Storm-Petrels (Oceanodroma leucorhoa). Jap. Women's Univ. J. 35: 129-133.

Taoka, M., Sato, T. \& Okumura, H. 1987. Sexual difference and vocal sex recognition in Purr Call of Leach's Srorm-Petrel (Oceanodroma leucorhoa). Jap. Women's Univ. J. 34: 113-117. (in Japanese)

Taoka, M., Sato, T., Kamada, T. \& Okumura, H. 1988. Situation-specificity in the vocalizations of Leach's Storm-Petrels (Oceanodroma leucorhoa). J. Yamashina Inst. Ornith. 20: 82-90.

Taoka, M., Sato, T., Kamada, T. \& Okumura, H. (in prep.). Sexual dimorphism of Chatter-calls and vocal sex recognition in Leach's Storm-Petrels. 


\section{コシジロゥミツバメ(Oceanodroma leucorhoa) の鳴声の異性間反応}

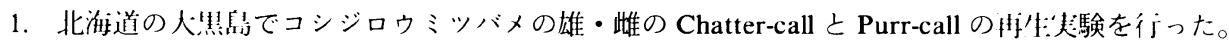

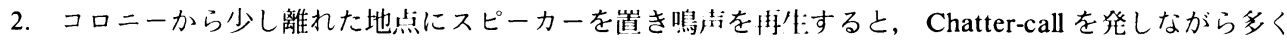
の率がト空に集まった。

3. 父忍した個体の性をその Chatter-call を分析して調べたところ，翼性の鳴声に㕈応していることがわ かった。

4. 巢分中の個体への再生奏験では，同性の鳴声に反応することが既にわかっている。従って，これらの 鳴声は再生夷験の方法の違いによって全く逆の性の個体の反心を引き起こすことが出来ることになる。

5.このことは同じ鳴声が状況の違いによって複数の意味を持つことを示している。

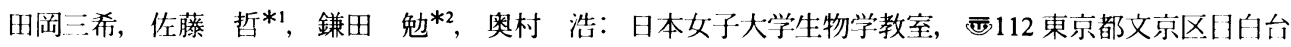
$2-8-1$

${ }^{* 1}$ : 京都大学理学部動物学教室, ${ }^{* 2}:$ 北海道大学歯学部口腔生理学教室 